\title{
Periods in the Use of Euler-Type Diagrams
}

\author{
Jens Lemanski \\ FernUniversität in Hagen \\ Universitätsstr. 33, KSW, \\ Hagen 58084, Germany \\ E-mail: jens.lemanski@fernuni-hagen.de
}

\begin{abstract}
Logicians commonly speak in a relatively undifferentiated way about pre-Euler diagrams. The thesis of this paper, however, is that there were three periods in the early modern era in which Euler-type diagrams (line diagrams as well as circle diagrams) were expansively used. Expansive periods are characterized by continuity, and regressive periods by discontinuity: While on the one hand an ongoing awareness of the use of Euler-type diagrams occurred within an expansive period, after a subsequent phase of regression the entire knowledge about the systematic application and the history of Euler-type diagrams was lost. I will argue that the first expansive period lasted from Vives (1531) to Alsted (1614). The second period began around 1660 with Weigel and ended in 1712 with Lange. The third period of expansion started around 1760 with the works of Ploucquet, Euler and Lambert. Finally, it is shown that Euler-type diagrams became popular in the debate about intuition which took place in the 1790 s between Leibnizians and Kantians. The article is thus limited to the historical periodization between 1530 and 1800 .
\end{abstract}

Keywords: diagrammatic reasoning, Euler diagrams, history of logic, logic diagrams

\section{Introduction}

Euler diagrams and Euler-type diagrams have been an increasingly used and investigated tool for the presentation of logical relations since the late $20^{\text {th }}$ century (Moktefi \& Shin, 2012; Legg, 2013). Euler diagrams are logic diagrams in the form of circles which illustrate the actual relation between concepts or classes. 
Here, the auxiliary term 'Euler-type diagram' refers to diagrams which have a similarity to those of Euler, but without necessarily referring to his own sketches. Today, it is well known that such logic diagrams were not first used by Leonhard Euler. The question of whether diagrams were used first in ancient, medieval, or early modern times is controversial (Stekeler-Weithofer, 1986, pp. 27-88; Edwards, 2006; Macbeth, 2014, pp. 58-107) and will not be discussed in what follows. More relevant is the fact that one can speak of an increasing use of Euler-type diagrams in early modern times over several centuries (Baron, 1969, p. 115).

Logicians commonly speak in a relatively undifferentiated way of pre-Euler diagrams: Peter Bernhard (2001, pp. 69-80) has summarized them under the title 'The use of diagrams before Euler'. Mark Greaves (2002, pp. 115-21) has compiled both Euler-type and other logic diagrams under the heading 'Early diagrams for Syllogistic Logic'. Amirouche Moktefi and Sun-Joo Shin (2012, p. 616) have explained that although there were diagrams before the $18^{\text {th }}$ century, it was only with Euler, who had popularized them through his systematics, that one could speak of a "golden age of logic diagrams" starting with him. These illustrative texts show that the authors emphasize the epochmaking achievement of Euler, but they are not concerned with a periodization of the early-modern diagrams. However, a chronological summary shows that there have always been very long periods of presence as well as absence of Euler-type diagrams in early modern times. Similar to an economic cycle, one can speak of 'periods of expansion and recession' in the history of Euler-type diagrams.

The thesis of the present paper, however, is that there were three periods in the early modern era in which Euler-type diagrams were expansively used. My criterion for a period consists of continuity as well as discontinuities: While on the one hand an ongoing awareness of Euler-type diagrams occurs during the expansive periods, these periods are followed by phases of regression in which the entire body of knowledge about the systematic application and the history of Euler-type diagrams is lost. Expansive periods are characterized by continuity, and regressive periods by discontinuity.

With the help of this criterion, I will argue that the first expansive period lasted from 1531 to 1614 . The second period began around 1660 and ended in 1712 . The third period of expansion started around 1760. The article is thus limited to the historical periodization between 1530 and 1800. Since I am mainly interested in exposing the continuities and breaks in history, I will only describe 
and explain some diagrams as examples. The focus of this article is rather on the reception history associated with the periodization.

\section{Period I (1531-1614)}

The first Euler-type diagram, found in a mechanically reproduced work, dates from 1531 by Juan Luis Vives. In the syllogism chapter of the second book of De censura veri et falsi, Vives first describes the classical syllogism. Then he explains the Aristotelian dictum de omni (et nullo) and the modus barbara, which he illustrates with a Euler-type diagram (Fig. 1; Vives, 1531, fol. 57v). Vives gives no indication of how this diagram is to be understood or whether he has taken this method of illustration from somewhere. The text and diagram correspond only to one sentence: Vives speaks of the fact that one can represent the transitive inference with three triangles ("vt si tres trianguli pingantur,..."; Vives, 1531, fol. $57^{\mathrm{v}}$ ). In many cases, logic historians have asked why Vives speaks in the text of triangles, yet the figure shows angles or V's (Lange, 1894, p. 10). Vives' diagram was first placed in a context with other logic diagrams in the early 19 th century (Denzinger, 1824, p. 66).

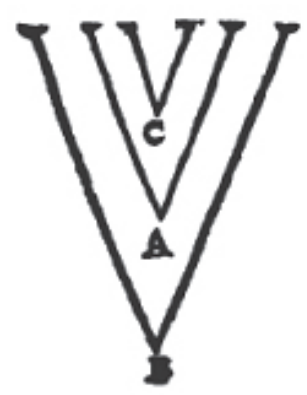

Figure 1. Vives' diagram

In 1589, two further intensively discussed diagrams are found in the logic of the astronomer Nicolaus Reimers (Ursus Dithmarsius), who was active in Strasbourg during this time. Already in the title of his book Metamorphosis Logicae, he announces his diagrams. His textbook on logic contains "a solid, highly evident and conspicuous exposition of the compelling reasoning" (Reimers, 1589, title 
page). The two circle diagrams found in the book refer to the dictum de omni (Fig. 2) and to the dictum de nullo (Fig. 3) (Reimers, 1589, pp. 32, 35). Reimers suggests several times that the diagrams are directly inspired by the metaphors of Aristotle. Apart from the Aristotelian and Ramistic logic, he criticizes all other

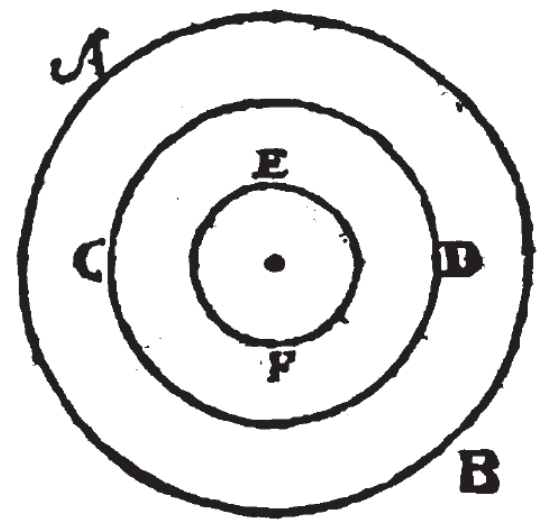

Figure 2. Ursus' diagram (dictum de omni)
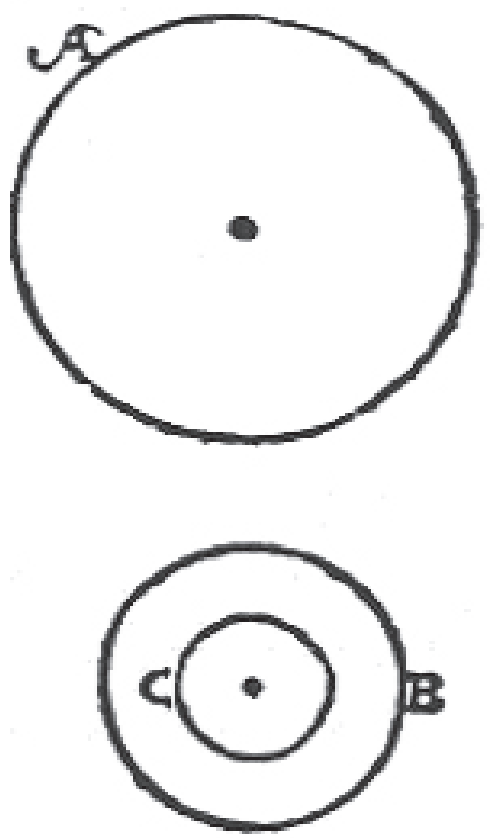

Figure 3. Ursus' diagram (dictum de nullo) 
logical textbooks. Thus, there is no direct historical reference to whether Reimers took over Euler-type diagrams from a predecessor. It was not until the late $20^{\text {th }}$ century that a relationship between Reimers' diagrams and Euler-type diagrams was mentioned (Risse, 1970, pp. 191-192).

The last two Euler-type diagrams in this period are found in Bartholomäus Keckermann in 1601 and 1603, as well as in Johann Heinrich Alsted in 1614. Keckermann uses line diagrams (Fig. 4) to explain why the first of the three Aristotelian figures and the dictum de omni are evident ("Dispositio huius figurae [sc. prima figura] evidens est"; Keckermann, 1601, p. 91). But there are two different versions of the same diagram: In 1601 it consists of equal lines (Fig. 4; Keckermann, 1601, p. 91), yet in 1603 the lines are of different length (Fig. 5; Keckermann, 1603, p. 429). In 1614, Alsted adopts the diagram ("diagramma") and the associated logical example of Keckermann from 1601 (Alsted, 1614,

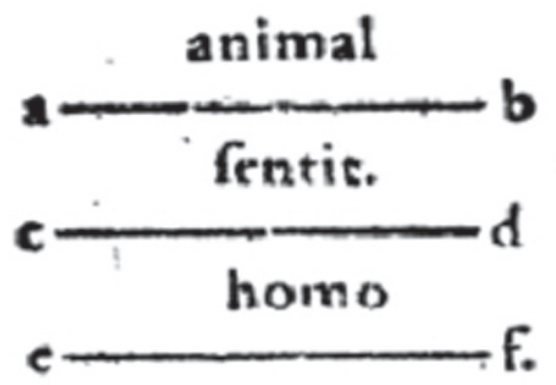

Figure 4. Keckermann's diagram (1601)

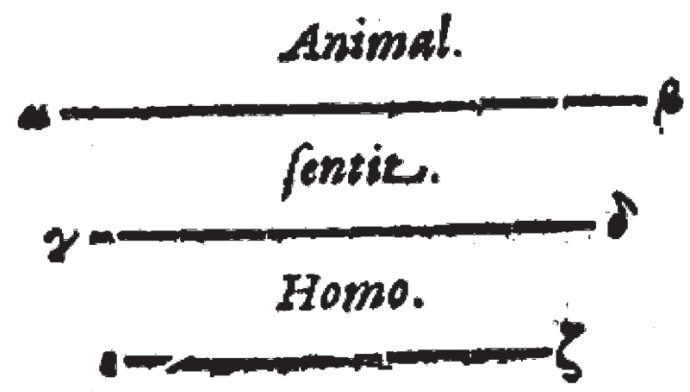

Figure 5. Keckermann's diagram (1603) 
p. 395) ${ }^{1}$ Although an explicit reference to the diagrammatic method cannot be found in either of the authors, it is very likely that both knew of Vives' Eulertype diagram. Alsted was a student of Keckermann and Keckermann often refers to Vives and praises him to the skies. While the diagrams of Alsted were already discussed in the $19^{\text {th }}$ century (Hamilton, 1860, p. 256), Keckermann's diagrams have not yet been mentioned in logic history.

The fact that Vives, Reimers, Keckermannn, and Alsted refer to their diagrams as an explanation of perfect syllogisms in relation to the dictum de omni (et nullo) reveals a similarity between all the authors and a continuity within the first period. Since Vives, Keckermann, and Alsted can be attributed to the same encyclopaedic movement, there is a historical continuity (Leinsle, 1988). In the widest sense, Reimers is attached to this tradition. But he falls out of the frame in so far as he mentions no other author of this period by name and in so far as his diagrams remained unknown for a long time.

\section{Period II (1660-1712)}

The second period consists of two schools that developed and used Euler-type diagrams independently of one another. The first school developed around Erhard Weigel in Jena and consists of Johann Christoph Sturm and Gottfried Wilhelm Leibniz; the second school was formed around Christian Weise in Zittau, and his students were Samuel Grosser and Johann Christian Lange. ${ }^{2}$

It is highly probable that within this period Weigel was the first to find the Eulertype diagrams around 1660. In later years, he explained that he had encountered Euler-type diagrams by interpreting Aristotelian metaphors (Weigel, 1669, p. 46). For this reason, he himself and some of his contemporaries spoke of "Weigelii inventa" in relation to his diagrams (Petri, 1704, p. 4; Weigel 1672, B 2). After several controversies within his university, Weigel was not permitted to publish his original logical theories. Perhaps for this reason, he sent his student Sturm to the liberal state of the Netherlands in order to make his invention public

\footnotetext{
$1 \quad$ I will not take into account the dispute between Venn and Hamilton (1860, p. 256) as to what extent the linear diagrams of Alsted actually anticipate Lambert's visualization method. However, Hamilton argues that Alsted had lines of different length (as in Fig. 5) in mind and the diagram is only misrepresented (as in Fig. 4). Venn (1894, pp. 422-423) sees this differently.

2 For a more detailed description of the second period see Lemanski, forthcoming.
} 
(Weigel, 1669, p. 47; Bullynck, 2013). Weigel's own diagrams were published much later, in 1693, in Philosophia Mathematica. Weigel used a peculiar method: instead of circles, triangles or lines, he used uppercase letters to represent all valid syllogistic forms, for example in Figure 6 (Weigel, 1693, I p. 122, II p. 105). But earlier, in 1661, Sturm published a book entitled Novi Syllogizandi Modi in Den Haag in which he used circle diagrams in order to prove unusual forms of syllogisms (Sturm, 1661).

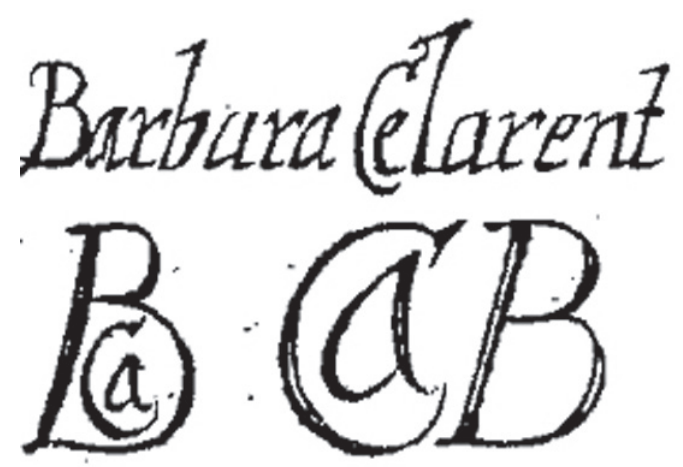

Figure 6. Weigel's diagram

In 1666 Leibniz published his dissertation in which he dealt with Euler-type diagrams. Leibniz criticized Sturm's method, arguing that it was not valid (Leibniz, 1666, p. 23). Yet, beginning in the late 1670s, Leibniz used circular and linear diagrams in several writings (Lenzen, 1990, pp. 15-21). These logical writings, however, remained mostly unpublished until the beginning of the $20^{\text {th }}$ century (Leibniz, 1903). ${ }^{3}$ In later years Leibniz confirmed that Weigel played a decisive role in the development of Euler-type diagrams in this period (Leibniz, 1710, pp. 390-391). Furthermore, Leibniz not only knew the diagrams of Weigel and Sturm, but he also had established contact with the Weise circle (especially with Lange) during his final years of life (Leibniz, 1768, V, pp. 404-405).

In parallel with the development of the Euler-type diagrams of Leibniz and Weigel, a second school developed not far from Jena. In the 1790s, Weise was president of the Gymnasium in Zittau and taught four hours of logic weekly. Many logicians and rhetoricians came out of his school. Although only a few tree diagrams can be found in Weise's books, it is astonishing that two of his students

3 The diagrams of Weigel and Sturm also became popular again in the $20^{\text {th }}$ century (Risse, 1970, p. 145; Scholz, 1961, pp. 118-119). 
have made intensive use of diagrams. Both students, Grosser and Lange, point verbally to a diagrammatic doctrine taught by Weise. In two books, published around 1797, Grosser uses a combination of a triangular and semicircular diagram in order to discuss the relationship between subject and predicate in judgments (Fig. 7; Grosser, 1697, pp. 117-118). ${ }^{4}$

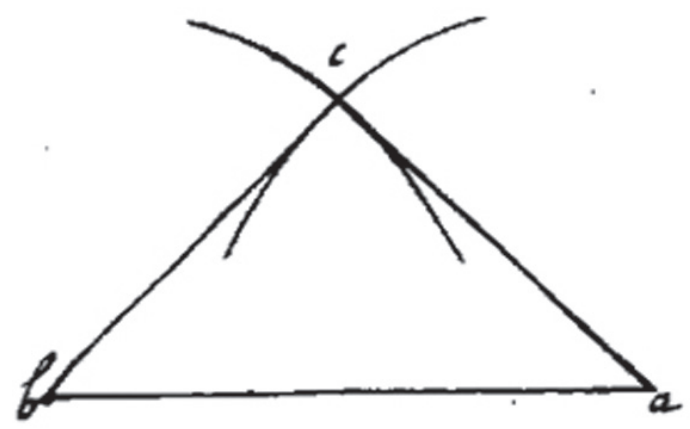

Figure 7. Grosser's diagram

After the death of Weise, Lange commented extensively on his teacher's principal work on logic. He published Weise's handbook of logic together with his 700 -page commentary in 1712 under the title Nucleus Logicae Weisianae. These comments contain numerous diagrams, in which Lange not only uses circles to illustrate syllogisms but also to represent exceptional cases of logic (such as sorites, etc., see Fig. 8). In addition, the book contains numerous notes on the history of logic diagrams (Weise \& Lange, 1712, pp. 248, 295, 707, 827). Lange explained that he was not only influenced by Weise, but also by Sturm und Grosser. Although Sturm's diagrams seemed to be related to his own circle diagrams, Lange presents arguments against Strum which are similar to those of Leibniz. Only later did he realize that Weigel had also used Euler-type diagrams. Regarding general logic diagrams, he traced the history back to the early sixteenth century. But concerning Euler-type diagrams, he explained that Weigel played an important role for Sturm, Weise, Grosser, and himself. Leibniz, Vives, Keckermann and Alsted were mentioned once, but not in connection with the history of the logic diagrams. A reference to Reimers is missing.

In sum, Lange's commentary is the most valuable guide to the development of logic diagrams in the time before Euler. In addition to Euler-type diagrams, he discusses numerous other diagram forms and related authors. Furthermore,

4 Because of the clearer representation, Figure 7 has been taken from the 1721 edition. 


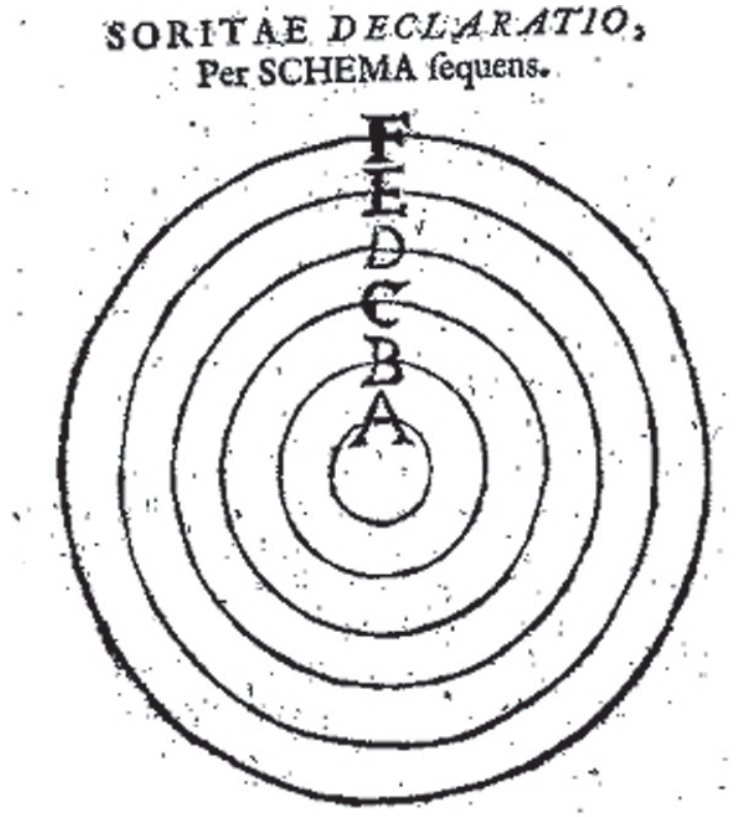

Figure 8. Lange's diagram

the work shows the subsequent link with all authors who used diagrams in the second period (except for Leibniz). He knew of diagrams from the first period, that is, before Weigel and Sturm, but he does not name Euler-type diagrams from the $16^{\text {th }}$ century. This indicates a clear gap between the two periods: Lange, like Weigel, Sturm, Leibniz, Weise and Grosser, knows many (or even all) Eulertype diagrams from the second period, but none from the first.

\section{Period III (1760-1880)}

In the period of the recession from 1712 to about 1760 , at least one person dealt with Euler-type diagrams. As recent studies prove, Euler already used circle diagrams in his notebook in the late 1730s (Kobzar, 2010). It is probable that he also used them for teaching purposes in Saint Petersburg. But in his diary as well as in Letters to a German Princess, On Different Subjects in Physics and Philosophy, written in 1762 and published in 1768, Euler gave no historical reference: Either Euler himself had the idea of using circle diagrams in logic, or for some reason he just did not specify from whom he acquired this method. 
Besides Euler, in the late 1750s and 1760s, Johann Heinrich Lambert and Gottfried Ploucquet still used line and square diagrams in a similar manner in logic. However, the fact that Lambert and Ploucquet argued intensively about who first had the idea to use Euler-type diagrams reveals the discontinuity between the third period and the other previous two.

Although Euler was the first to have the idea in this period, Ploucquet was the first logician to publish Euler-type diagrams in the third period (Bellucci, Moktefi \& Pietarinen, 2014). He published his squares (Fig. 9) in Fundamenta Philosophiae Speculativae as early as 1759, without any historical comment (Ploucquet, 1759, p. 25). It was not until 1763 that Lambert published his diagrams in his Neues Organon. At first he only learned from Georg Jonathan von Holland (1764) that Ploucquet had also used Euler-type diagrams. He probably assumed that he and Ploucquet had published their diagrams at about the same time (Wolters, 1980, pp. 120-122). For this reason, Lambert reported that already in 1762 he had found an "old scholastic logic, or a commentary on the logic of Aristotle" with logical "figures in woodcut" in the citizens' library of the Zurich Water Church, which illustrated "many concepts and relations" (Lambert, 1782, vol. 1, pp. 403-408). Because of this book, Lambert came to the idea to develop Eulertype diagrams. Ploucquet informed Lambert that his diagrams had already been published in 1759 and that he had had the idea a year earlier (Ploucquet, 1765, p. 8).

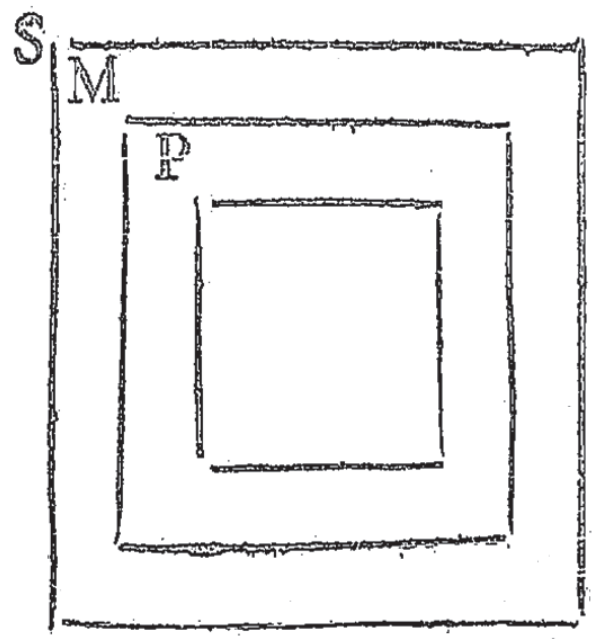

Figure 9. Ploucquet's diagram 
In the 1760s, Ploucquet sought out precursors of his calculus. By referring to historical notes in Johann Jakob Brucker and Heinrich Wilhelm Clemm, he denied that Richard Suiseth and Ramon Llull were forerunners of his method (Ploucquet, 1765, pp. 10-14). He also points to a work by Lange (Inventum Novum Quadrati Logici Universalis), in which there are diagrams: While Lange himself interpreted them as Euler-type diagrams, Ploucquet only talks about their subordination method (Ploucquet, 1763, p. 22). In 1771, Lambert also wrote some historical notes on Euler-type diagrams (Lambert, 1771, vol. 1, pp. XIII, XXI, 128). He had recently found the commentary of Lange's Nucleus Logicae Weisianae from the second period. As described above, Lange's commentary to the Nucleus Logicae Weisianae contained more obvious Euler-type diagrams than the book that Ploucquet had discovered. In principle, Lambert explained, Lange's diagrams were the same as those of Euler. But for Lambert, his own method was more closely related to that of Ploucquet. Moreover, he does not know about the history of Euler-type diagrams. Lambert's discovery of Lange's diagrams, however, was not taken into account for more than sixty years. Only Moritz Wilhelm Drobisch (1827, p. 5) and later Friedrich Ueberweg (1857, p. 225) referred back to Lambert's discovery of Lange's diagrams.

Although Lambert's and Ploucquet's methods had been widely discussed in the mid-1760s, the public interest declined sharply. Euler's logic diagrams and his metaphysics, published in 1768, were not discussed by professors of philosophy, especially in German-speaking countries. Euler's letters were reproduced several times until the end of the 1780s and translated into German in 1769; however, a philosophical reception of his logic was initially lacking. The philosophical reception of the logic of Ploucquet, Euler and Lambert began only twenty years after the publications. Only in the 1790s did Kantian and later Kant-opponents mention and use the first Euler-type diagrams. Thus, it does not suffice to speak only of three periods in early modern times in which Euler-type diagrams were used. One must also divide the third period into several sections. The first section begins with Ploucquet, Lambert and Euler, and the second section with Kantians and Kant-critics.

Immanuel Kant himself used numerous diagrams in his logic lectures in Königsberg (AA XVI, p. 726; Fig. 10), and some of them were Euler diagrams (Lu-Adler, 2012): At one point, in 1772, Kant explicitly spoke in his lectures of "Euler's [...] figures" (AA XXIV/I, p. 454). However, since his lectures contain many more traditional diagrams that Euler did not use, the Letters to a German Princess cannot have been his only source (and also not Lambert's Neues Organon 
1.

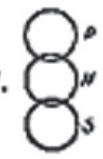<smiles>C1CCC23CCCC2CCCC3C1</smiles><smiles>C1CCC23CCCCC2CCCC3C1</smiles><smiles>c1ccc2c(c1)CCCC2</smiles><smiles>O=C(CO)CCO</smiles><smiles>C1CC2CCCC(C1)OC2</smiles><smiles>O=CCO</smiles>
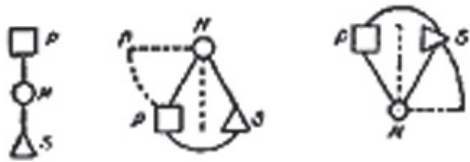

Die bende \$auptbegrifie finb nebell eiranber.

1.
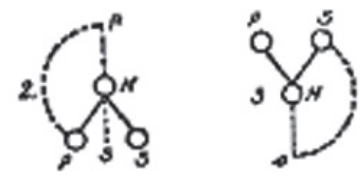

( ${ }^{s}$ metathesis praemissarum)

(" find neben, nidt unter eimander.)
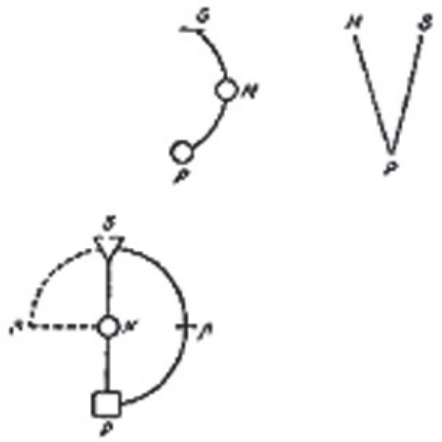

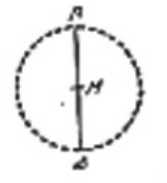

$\underbrace{\circ}$

Figure 10. Kant's diagrams

or Ploucquet's Fundamenta Philosophiae Speculativae). Kant knew Lambert's writing with Euler-type diagrams, but whether he also knew Ploucquets' diagrams or whether he was interested in his criticism at all is uncertain. ${ }^{5}$ But it was not until 1800 that Gottlob Benjamin Jäsche published a compilation of these logic lectures (including diagrams), which became pioneering for the $19^{\text {th }}$ century (Kant, 1800).

Previously, however, there was a dispute about the validity and development of geometrical figures and logic diagrams between Leibnizians and Kantians. Since the middle of the 1780s, Leibnizians had criticized the function of intuition in geometry, which Kantians had just pointed out (Allison, 1973, pp. 1-104;

5 For a detailed description of the reception of Lambert by Kant cf. Peckhaus, 1997, pp. 110-120. 
Koriako, 1999, \$24). In addition to this long-standing discussion on intuition in geometry, a second debate about the history and relevance of logic diagrams developed. Rather neutral are the logics of Johann August Heinrich Ulrich (1785, p. 148) and Gotthelf Samuel Steinbart (1787, pp. 14-17), but the two use only linear diagrams.

Later, in the logic debate, Leibnizians appealed to the Kant-critic Ploucquet and tried to harmonize him with Lambert: The anti-Kantian Johann Gebhardt Ehrenreich Maaß (1793; Bernhard, 2007) used triangles in his logic based on Lambert's line diagrams. In his opinion, Euler's diagrams are "useless" (Maaß, 1793, p. IX). The Leibnizian Wilhelm Ludwig Gottlob von Eberstein (1794, pp. 93, 302, 454) wrote that Ploucquet was the first one to use squares, followed by Lambert's use of lines, and finally Maaß's triangles in syllogistics. Eberstein (1794, p. 244) mentions Euler only once in connection with the critics of the monad doctrine (Knobloch, 2010). These critics are strongly abused by Eberstein. At the beginning of the 1790s, there was even a German edition of Letters to a German Princess, in which the sections on logic and metaphysics (directed against Leibniz and Wolff) were excluded. The publisher explained that there was no "general interest" in Euler's logic and metaphysics; furthermore, both sections were strongly in need of modernization (Euler, 1792/1793, vol. 1, p. V). German supporters of Leibniz and Wolff welcomed the reduction of this work to its scientific content (Br., 1793).

In contrast to the Leibnizians, the Kantians expressed the opinion in the 1790s that Lambert was more in harmony with Euler and that both were forerunners of Kant. Johann Gottfried Kiesewetter, who had studied in Königsberg in 1788, used circle diagrams in order to illustrate rules of conversion (Kiesewetter, 1793, pp. 125-127). Particularly relevant is Georg Samuel Albert Mellin (1799, pp. 581-611), who linked Kant's The False Subtlety of the Four Syllogistic Figures with Euler's and Lambert's logic. In a table at the end of the book, he contrasts eight line diagrams of Lambert with eight circle diagrams of Euler (Fig. 11).

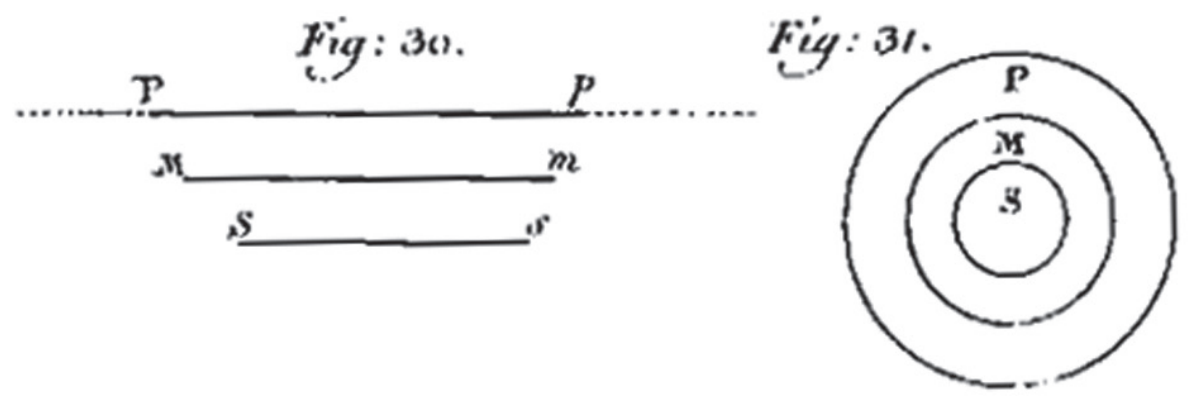

Figure 11. Mellin's diagram 
On the basis of these different perspectives, we can assume that the term 'Euler diagrams' is used today only for the reason that Kantians have prevailed to a certain extent against Leibnizians. However, with the appearance of the Jäschelogic, the reception of logic diagrams began to strengthen from 1800 onwards. It was only with the discovery of the 'Weierstrass monsters' and the so-called 'new logic' of Frege that the reception suddenly stopped in the German-speaking world in about 1880. From then on, formalism prevailed in Central Europe and the use of Euler-type diagrams remained a second-class approach in logic until the end of the $20^{\text {th }}$ century (Bernhard, 2001, pp. 11-17).

\section{Conclusion}

I have argued that there have been three periods of Euler-type diagrams in early modern history. The first period began with Vives, whose diagram was taken by Keckermann and Alsted. Reimers remained an outsider in this period. The second period consisted of two schools: the Weigel circle with Weigel as the teacher of Sturm and Leibniz, as well as the Weise circle with Weise as the teacher of Grosser and Lange. In this period, Leibniz was aware of the published diagrams of Weigel and Sturm; furthermore, Lange knew of all the published Euler-type diagrams of this period. There was, however, no indication that the authors of the second period knew about the Euler-type diagrams of the first period.

This was similar in the third period. Ploucquet and Lambert argued in the 1760s about who had invented Euler-type diagrams. Euler did not comment on the history of the diagrams. Lambert found in later years Lange's Euler-type diagrams from the second period. This historical note, however, was only taken up again many decades later. To this extent, the third period also has a discontinuity with the other two periods. However, I have also suggested that further sections should be mentioned within the third period. While the diagrams of Lambert and Ploucquet were discussed intensively in the 1760 s, the discussion thereafter sharply diminished. It was not until the 1790s that Euler-type diagrams were recalled by logicians in connection with the debate between Leibnizians and Kantians on intuition in geometry and logic. The connections and interruptions between the authors of the three periods can be viewed on the accompanying diagram (Fig. 12). 

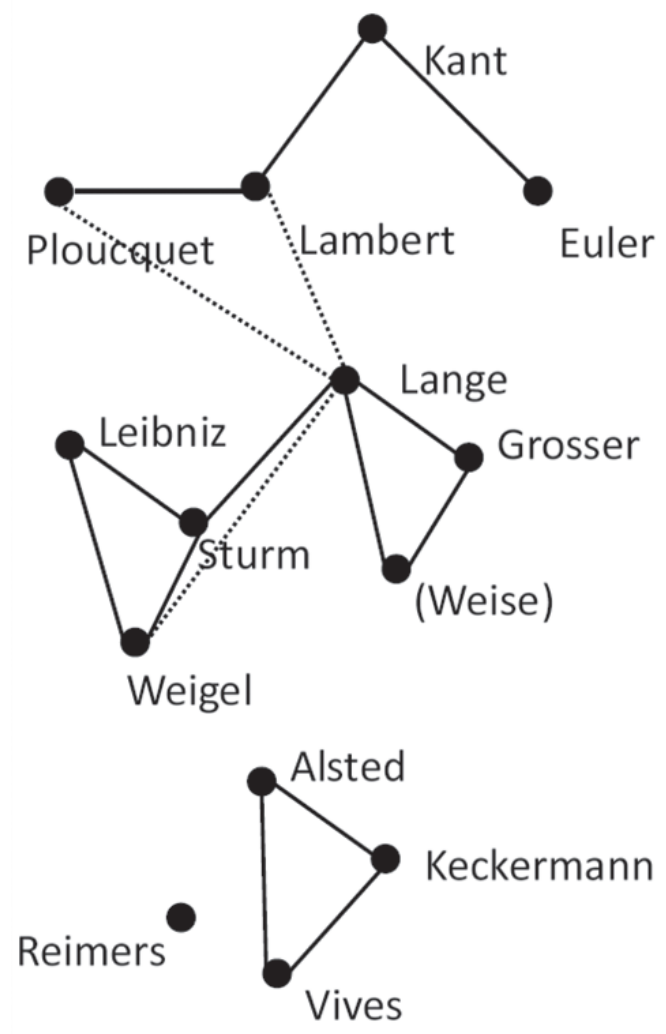

Figure 12. This Hasse-type diagram shows the proven, or highly probable, influence from one author to another (indicated by solid lines). Dotted lines illustrate the fact that an author later became aware of the other author.

The individual sections of the third epoch have not yet been explored. Neither is it known how many schools or sections this period has, nor whether it makes sense to look for further sections in this period. In connection with the research of this period, the question arises as to when Euler emerges for the first time as a prominent name for logic diagrams and when exactly the term 'Euler diagrams' finds itself in literature. It also remains questionable whether the expansion of logic diagrams since the 1990s can still be assigned to a section of the third period. 


\section{Acknowledgments}

The paper introduces research that was presented at some scientific events during May 2017 in Estonia, including a philosophical seminar at Tallinn University of Technology (May 15, 2017) and the $28^{\text {th }}$ Baltic Conference on the History of Science in Tartu (May 18-20, 2017), and benefited from discussions in those events. I especially thank Ahti-Veikko Pietarinen, Amirouche Moktefi, Daniele Chiffi, Peeter Müürsepp, Eberhard Knobloch, Jon Regan and the two anonymous reviewers for helpful comments.

\section{References}

AA (1900-), Immanuel Kant: Gesammelte Schriften (Akademie-Ausgabe), ed. by Preußische/Deutsche/Göttinger/Berlin-Brandenburgische Akademie der Wissenschaften. Berlin: Preußische/Deutsche/Göttinger/Berlin-Brandenburgische Akademie der Wissenschaften.

Allison, H. E. (1973), The Kant-Eberhard-Controversy, Baltimore \& London: The Johns Hopkins University Press.

Alsted, J.-H. (1614), Logica Systema Harmonicum..., Herbornæ Nassoviorum: s.e.

Bellucci, F.; Moktefi, A. \& Pietarinen, A.-V. (2014), 'Diagrammatic Autarchy. Linear Diagrams in the 17th and 18th Centuries,' in J. Burton \& L. Choudhury (eds.) Diagrams, Logic and Cognition, CEUR Workshop Proceedings, vol. 1132, pp. 23-30.

Bernhard, P. (2001), Euler-Diagramme: Zur Morphologie einer Repräsentationsform in der Logik, Paderborn: Mentis.

(2007) 'The Remarkable Diagrams of Johann Maass,' in G. Löffladt (ed.) Mathematik-Logik-Philosophie: Ideen und ihre historischen Wechselwirkungen, Frankfurt am Main: Harri Deutsch, pp. 83-93.

Br. [= Mayer, J. T.] (1793), 'Leonhard Eulers Briefe über verschiedene Gegenstände aus der Naturlehre...,' Intelligenzblatt der neuen allgemeinen deutschen Bibliothek, vol. 21, pp. 558-559.

Bullynck, M. (2013), "Erhard Weigel's Contributions to the Formation of Symbolic Logic," History and Philosophy of Logic, vol. 34, no. 1, pp. 25-34. https://doi.org/10.1080/01445340.2012.726855

Denzinger, I. (1824), Institutiones logica, vol. II, Leodii: Collardin.

Drobisch, M. W. (1827), De calculo logico, Lipsiae: Melzer.

von Eberstein, W. L. G. (1794), Versuch einer Geschichte der Logik und Metaphysik bei den Deutschen von Leibniz bis auf die gegenwärtige Zeit, Halle: Joh. Gottfr. Ruff. 
Edwards, A. W. F. (2006), 'An Eleventh-Century Venn Diagram,'BSHM Bulletin: Journal of the British Society for the History of Mathematics, vol. 21, pp. 119-121. https://doi.org/10.1080/17498430600804407

Euler, L. (1792/93), Briefe über verschiedene Gegenstände aus der Naturlehre, ed. by F. Kries, 2 vol., Leipzig: Dyck.

- (1768), Lettres à une princesse d'Allemagne sur divers sujets de physique \& de philosophie, 2 vols., Saint Petersbourg: Academie Impérial des Sciences.

Gardner, M. (1958), Logic Machines and Diagrams, New York, Toronto \& London: Mcgraw-Hill Book Company.

Greaves, M. (2002), The Philosophical Status of Diagrams, Stanford: CSLI.

Grosser, S. (1697), Gründliche Anweisung zur Logica..., Budißin \& Görlitz: Johann Wilisch.

Hamilton, W. (1860), Lectures on Metaphysics and Logic, ed. by H. L. Mansel \& J. Veitch, vol. 3, Edinburgh \& London: William Blackwood and Sons.

Holland, G. J. (1764), Abhandlung über die Mathematik, die allgemeine Zeichenkunst und die Verschiedenheit der Rechnungsarten: Nebst einem Anhang, worinnen die von Hrn. Prof. Ploucquet erfundene logikalische Rechnung gegen die Leipziger neue Zeitungen erläutert und mit Hrn. Prof. Lamberts Methode verglichen wird, Tübingen: Cotta.

Kant, I. (1800), Logik: Ein Handbuch zu Vorlesungen, ed. by G. B. Jäsche, Königsberg: Nicolovius.

Keckermann, B. (1601), Systema Logica: Sompendiosa methodo..., Hanoviae: Guilielmus Antonius.

(1603), Systema Logica: Tribus Libris Adornatvm..., Hanoviae: Guilielmus Antonius.

Kiesewetter, J. G. (1793), Grundriß einer reinen allgemeinen Logik nach kantischen Grundsätzen..., Frankfurt \& Leipzig: s.e.

Knobloch, E. (2010), 'Leonhard Euler als Theoretiker,' in W. Velminski \& H. Bredekamp (eds.) Mathesis \& Graphe: Leonhard Euler und die Entfaltung der Wissensysteme, Berlin: Akademie, pp. 19-36. https://doi.org/10.1524/9783050088235.19

Kobzar, V. I. (2010), “Gnoseologiia i logika L. Eilera v 'Pismakh k nemetskoi printsesse o raznykh fizicheskikh i filosofskikh materiiakh', Logiko-filosofskie studii, vol. 8, pp. 98-120.

Koriako, D. (1999), Kants Philosophie der Mathematik: Grundlagen-VoraussetzungenProbleme, Hamburg: Meiner.

Lambert, J. H. (1771), Anlage zur Architectonic, oder Theorie des Einfachen und des Ersten in der philosophischen und mathematischen Erkenntniß, 2 vols., Riga: Johann Friedrich Hartknoch.

(1764), Neues Organon oder Gedanken über die Erforschung und Bezeichnung des Wahren und dessen Unterscheidung vom Irrthum und Schein, 2 vols., Leipzig: Johann Wendler. 
(1782), Deutscher gelehrter Briefwechsel, ed. by J. Bernoulli, 2 vols., Berlin: Johann Bernoulli.

Lange, F. A. (1894), Logische Studien: Ein Beitrag zur Neubegründung der formalen Logik und der Erkenntnistheorie, Iserlohn: Julius Baedeker.

Legg, C. (2013), 'What is a Logical Diagram?' in S.-J. Shin \& A. Moktefi (eds.) Visual Reasoning with Diagrams, Basel: Birkhäuser, pp. 1-18. https://doi.org/10.1007/978-3-0348-0600-8_1

Leibniz, G. W. (1903), Opuscules et fragments inédits de Leibniz: Extraits des manuscrits de la Bibliothéque royale de Hanovre, ed. by L. Couturat, Paris: Félix Alcan.

- (1710), Essais de théodicée, sur la bonté de Dieu, la liberté de l'homme, et l'origine du mal, Amsterdam: Isaac Troyel.

(1768), Opera omnia nunc primum collecta, in classes distributa, prafationibus et indicibus exhornata, studio Ludovici Dutens, Genevæ: Fratres de Tournes.

(1666), Dissertatio de arte combinatoria..., Lipsiae: Joh. Simon Fickium et Joh. Polycarp. Seuboldum.

Leinsle, U. G. (1988), Reformversuche protestantischer Metaphysik im Zeitalter des Rationalismus, Augsburg: Maro Verlag.

Lemanski, J. (forthcoming), 'Logic Diagrams in the Weigel and Weise Circles,' in History and Philosophy of Logic.

Lenzen, W. (1990), Das System der Leibnizschen Logik, Berlin \& New York: de Gruyter.

Lu-Adler, H. (2012), Kant's Conception of Logical Extension and Its Implications, PhD thesis, University of California. Retrieved from https://philpapers.org/rec/LUAKCO [accessed May 2017]

Maaß, J. G. E. (1793), Grundriß der Logik, zum Gebrauche bei Vorlesungen, Halle: Michaelis und Compagnie.

Macbeth, D. (2014), Realizing Reason: A Narrative of Truth and Knowing, Oxford: Oxford University Press. https://doi.org/10.1093/acprof:oso/9780198704751.001.0001

Mellin, G. S. A. (1799), Encyclopädisches Wörterbuch der kritischen Philosophie, vol. 2, sect. 2, Jena \& Leipzig: Friedrich Frommann.

Moktefi, A. \& Shin, S.-J. (2012), 'A History of logic diagrams', in D. M. Gabbay, F. J. Pelletier \& J. Woods (eds.) Logic: A History of its Central Concepts, Burlington: Elsevier Science, pp. 611-683. https://doi.org/10.1016/B978-0-444-529374.50011-3

Peckhaus, V. (1997), Logik, Mathesis universalis und allgemeine Wissenschaft: Leibniz und die Wiederentdeckung der formalen Logik im 19. Jahrhundert, Berlin: Akademie.

Petri, J. G. (1677), Deus in naturae admirandis repraesentatus, \& Serenissimo Principi Lotharingiae \& Voudemont, Francofurti: Waltheri.

Ploucquet, G. (1759), Fvndamenta Philosophie Speculative, Tubingae: Joh. Georg. Cotta. 
— (1763), Methodvs Calcvlandi in Logicis, Francofurtum, Lipsiae: s. e.

- (1765), 'Untersuchung und Abänderung der logikalischen Constructionen des Hrn. Prof. Lambert,' in Bök (ed.) Sammlung der Schriften, Tübingen: Johann Georg Cotta, pp. 157-202.

Reimers (Raymarus Ursus Dithmarsius), N. (1589), Metamorphosis Logicae..., Argentoratum: s. e.

Risse, W. (1964), Die Logik der Neuzeit: Vol. 1: 1500-1640, Stuttgart-Bad Cannstatt: Frommann-Holzboog.

__ (1970), Die Logik der Neuzeit: Vol. 2: 1640-1780, Stuttgart-Bad Cannstatt: Frommann-Holzboog.

Scholz, H. (1961), Concise History of Logic, transl. by K. F. Leidecker, New York: Philosophical Library.

Steinbart, G. S. (1787), Gemeinnützige Anleitung des Verstandes zum regelmäßigen Selbstdenken, $2^{\text {nd }}$ ed., Züllichau: Frommanns Erben.

Stekeler-Weithofer, P. (1986), Grundprobleme der Logik: Elemente einer Kritik der formalen Vernunft, Berlin \& New York: de Gruyter.

Sturm, J. Chr. (1661), Universalia Euclidea...: Accedunt ejusdem XII. Novi Syllogizandi Modi in propositionibus absolutis, cum XX. aliis in exclusivis, eâdem methodo Geometricâ demonstrates, Hagæ-Comitis: Adrianus Vlaccq.

Ueberweg, F. (1857), System der Logik und Geschichte der logischen Lehren, Bonn: Marcus.

Ulrich, I. A. H. (1792), Institvtiones logicae et metaphysicae: Scholae svae scripsit perpetva Kantianae disciplinae ratione habita, Ienae: Croekeria.

Venn, J. (1894), Symbolic Logic, London: Macmillan.

Vives, I. L. (1531), 'De censura veri et falsi,' in De disciplinis Libri XX, Tertio tomo de artibus libri octo, Antverpia: Michael Hillenivs.

Weigel, E. (1669), Idea Matheseos universe cum speciminibus Inventionum Mathematicarum, Jenae: Bauhoferus.

- (1672), Neu-erfundener Hauß-Rath / so wohl zur Nothdurfft / als zur Lust und Bequemligkeit/ zu gebrauchen, Jena: Bauhofer.

__ (1693), Philosophia Mathematica: Archimetria, Jenæ \& Helmstad: Matth. Bircknerus.

Weise, C. \& Lange, I. C. (1712), Nvclevs Logicae Weisianae: [...] illustrates [...] per varias schematicas [...] ad ocularem evidentiam deducta..., Gissa-Hassorum: Henningius Müllerus.

Wolters, G. (1980), Basis und Deduktion: Studien zur Entstehung und Bedeutung der Theorie der axiomatischen Methode bei J.H. Lambert (1728-1777), Berlin \& New York: de Gruyter. 
Jens Lemanski studied Philosophy and Biology at the universities of Bochum, Mainz and Lecce. He holds a PhD in Philosophy from the Johannes GutenbergUniversität Mainz and the Università del Salento. As a research fellow for Theoretical Philosophy at the FernUniversität in Hagen he specializes in logic and philosophy of science. With regard to the interpretation and evaluation of logic diagrams, he adopts the standpoint of 'rational representationalism'. 